\title{
THE DRYOPTERIS DILATATA COMPLEX IN MACARONESIA AND THE IBERIAN PENINSULA
}

\author{
M. GIBBY
}

SUMMARY: Diploid and tetraploid species of the Dryopteris dilatata complex are found in Spain and Portugal. In an attempt to determine the relationships between species the cytology of both wild and synthetised hybrids has been investigated, and the results obtained so far will be described.

RESUMEN: Se han encontrado especies diploides y tetraploides del complejo Dryopteris dilatata en España y Portugal. Para determinar el parentesco entre las especies se ha estudiado la citología de los híbridos tanto naturales como artificiales, exponiéndose finalmente los resultados obtenidos.

Ten species are at present recognised as belonging to the Dryopteris dilatata (Hoffm.) A. Gray complex, eight of which can be found within the region of Macaronesia and the Iberian Peninsula. The other two species of the complex are native to eastern North America. Of the ten species of the complex, five are diploid, with 82 chromosomes $(2 n=82$; see Plate 1$)$ and five are tetraploid, with $2 n=164$ (Plate 2).

D. dilata itself is a tetraploid with an ovate-deltoid lamina that is mid to dark green in colour, and somewhat glandular, with sparse stalked glands. The scales at the stipe base are triangular to linear in shape, usualy with a distinct broad dark central stripe. The rhizome is upright and the fronds have a lax growth form. An importan distinguishing character is the length of the lowest innermost basiscopic pinnule which is usually equal in length to its neighbour; this distinguishes D. dilatata from some of the diploid species of the complex. D. dilatata has relatively large spinulose spores, $35-48 \mu \mathrm{m}$ in length.

The distribution of the species in Macaronesia and the Iberian Peninsula is described in Table 1. Only one species, the diploid D. aemula (Aiton) $O$. Kuntze, is found throughout the region. It is recognised by its triangular frond, dark brown or purplish stipe, dark concolorous scales, spineless spores, 31-39 $\mu \mathrm{m}$ in length, upcurling pinnule margins and the presence of many pale green or white sessile glands on the lamina, which give the fern its characteristic smell of coumarin when dried. This is a common fern in the Azores and Madeira, but it has a much more restricted distribution 
in the Canary Islands, being recorded so far only from the El Cedro region of Gomera. In the Iberian Peninsula it is most frequent in Galicia. Several of the other species appear to be island endemics. D. azorica (Christ) Alston $(2 n=82$; Plante 1$)$ and D. crispifolia Rasbach, Reichstein \& Vida $(2 n=164$; Plate 2$)$ occur only on the Azores; D. azorica has been recorded from all the islands except Corvo and Graciosa (Gibby et al., 1977) whilst D. crispifolia is probably limited to Pico and Faial. D. azorica has an ovate-deltate frond and the ultimate segments are broad and often touching which gives the frond a dense silhouette; glands are absent but the costae of the pinnules bear small brown scales, and the lowest innermost basiscopic pinnule is usually shorter than its neighbours, and often overlaps the rachis. The scales at the base of the stipe have a dark line, and the spore size is small, 28-38 $\mu \mathrm{m}$ in length. D. crispifolia is characterised by its very crisped appearance, which is quite distinct from any other European Dryopteris. Scales on the stipe base are dark brown, sometimes showing a dark line, and long and narrow in shape with a pointed tip. The lamina is covered with greenish white sessile glands, like D. aemula and the frond smells of coumarin. The midribs of the pinnae and pinnules bear small brown scales. Pinnules and pinnule segments are broad and often overlapping. The spore size is large, 35-45 $\mu \mathrm{m}$. D. maderensis Alston ( $2 \mathrm{n}$ $=82$ ) is a laurel forest species occurring only in Madeira. It is similar to D. azorica in having a small spore size $(30-36 \mu \mathrm{m})$, and a short lowest innermost basiscopic pinnule. The scales on the stipe base are dark brown and the lamina lacks glands but also lacks the small brown scales that are seen on the pinnules of D. azorica. The pinnules and pinnule segments of $D$. maderensis are narrower and not overlapping or touching, and both are deflexed from the midribs; the ultimate teeth may upturn.

Dryopteris guanchica Gibby \& Jermy $(2 \mathrm{n}=164)$ has an ovate-deltate lamina, distinctly stalked pinnules and lanceolate brown concolorous scales at the stipe base. On the lowest pairs of pinnae, the upper innermost pinnule is often distinctly smaller than its neighbours. The frond is usually flat, with upturned teeth, and the spores are large, 35-47 $\mu \mathrm{m}$ long. This species was first believed to be endemic to the Canary islands. It is recorded from Tenerife, Gomera and La Palma, although it is probably extinct in La Palma now. Míre recently it has been found to be present in the Iberian Peninsula. Amongst herbarium specimens from the Botanical Institute in Coimbra, Portugal, some specimens of D. guanchica were identified; these had been collected in the serra da Cintra, near Lisboa in 1839, probably by Welwitsch. During a visit to the same area in 1976 Dyce, Gibby and Jermy confirmed that D. guanchica is still growing at this site. Subsequently material of D. guanchica has been identified from northern Portugal and north-west Spain.

Dryopteris expansa (C. Presl) Fraser-Jenkins and Jermy $(2 \mathrm{n}=82)$ and D. carthusiana (Vill.) H.P. Fuchs $(2 \mathrm{n}=164)$ have not been recorder from Macaronesia, and their distribution in the Iberian Peninsula is limited mainly to the north-east and north-west. D expansa is similar to D. dilatata in morphology, but the segments are more finely divided, the lamina is lighter green in colour and the scales are not usually so dark, being sometimes ginger and concolorous, or with a darker central stripe. The lowest innermost basiscopic pinnule is usually long, often twice as long as its neighbour, in comparison with D. dilatata where these are usually similar in length. As a result the lowest pinnae of $D$. expansa are distinctly triangular in shape. The spores are large in D. expansa $(35-48 \mu \mathrm{m})$, simi- 
lar in size to those of D. dilatata. D. carthusiana is characterised by pale brown concolorous stipe scales, and a creeping rhizome (unlike the other species of the complex, where the rhizome is upright); the fronds have an upright habit, a flat lamina without glands, and distinctive spinulose teeth on the pinnules. The stipe and lamina are usually equal in length, whereas in D. dilatata the stipe is usually half to two-thirds the length of the lamina. The spores of D. cartthusiana are large, 35-47 $\mu \mathrm{m}$ in length.

Records for D. dilatata throughout the region have long been confused, largely because it is only recently that D. azorica, D. expansa, D. maderensis, D. crispifolia and D. guanchica have been recognised as separate species. D. dilatata does have a fairly wide distribution in the Iberian Peninsula, but its presence in Macaronesia has been in doubt (Gibby et al., 1977), However, some collections of Dryopteris from Pico by Sjögren are referable neither to D. aemula, D. azorica or D. crispifolia, and the morphology of these specimens looks very similar to that of D. dilatata from Europe. Recently Fraser-Jenkins has revisited the site of this material in Pico and collected living specimens. Root squashes of one plant show it to be tetraploid, with 164 chromosomes, and this, together with morphological similarities, suggests that it is indeed D. dilatata.

The inter-relationships of these eight species within the complex have been determined by cytogenetic studies, based on analysis of meiosis in both wild and synthesised hybrids involving these and other Dryopteris species. The methods that were used in the synthesis of hybrids have been described in detail by Lovis (1968); meiotic preparations were made by the aceto-carmine squash technique of Manton (1950). For mitotic preparations actively growing root tips were pre-ireated in a saturated solution of alphabromonaphthalene, fixed in $3: 1$, absolute alcohol: glacial acetic acid and stored in refrigerator at $-20^{\circ} \mathrm{C}$.

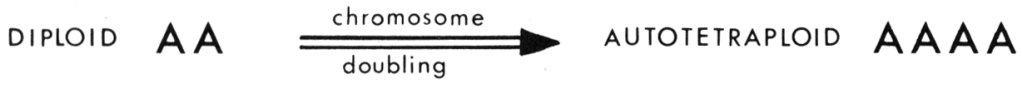

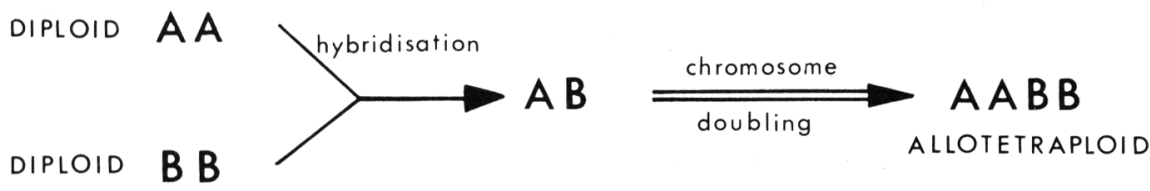

Figure 1.- Diagrammatic representation of the formation of an autotetraploid and an allotetraploid. A and B represent non-homologous genomes. 
Tetraploids can be classified into basic types, autotetraploid and allotetraploid. The former is derived from a diploid by chromosome doubling, whereas the latter is derived from two different diploid species, by hybridisation and chromosome duplication (see Fig. 1). A diploid can be represented as AA where A represents a chromosome set or genome; in Dryopteris each genome consists of 41 chromosomes. The two chromosome sets in the diploid can pair at meiosis, forming 41 bivalents and so they are said to be homologous, and are represented by the same letter. The autotetraploid has four homologous chromosome sets and is represented as AAAA (Fig. 1). The allotetraploid is designated AABB because it is derived from two different diploids, whose genomes are not homologous. In theory an autotetraploid should form quadrivalents during the first division of meiosis, and an allotretraploid should form only bivalents. However, autotetraploid ferns are normally bivalent - forming, probably as a result of some genetic control of chromosome pairing. In the investigation of the complex, attempts were made to determine whether the tetraploid species are auto- or allo-polyploids, and to determine their origin.

Dryopteris dilatata was shown to be an allotetraploid by Manton and Walker (1954), who described meiosis in a dihaploid sporophyte of D. dilatata; this had arisen directly from a prothallus of D. dilatata without fusion of gametes, and so possessed the gametic number of chromosomes. This dihaploid showed only univalents during the first division of meiosis (Plate 3); this suggests that the two genomes involved are not closely related, and that D. dilatata has had an allopolyploid origin. D. expansa $(2 n=82)$ has been identified as one of the parents of D. dilatata. Triploid hybrids of D. dilata x expansa have been synthesised by Walker (1955) and Gibby (1977); in addition, hybrids of this combination form readily in the wild, and can be found where the two species grow together. The wild triploid hybrid has been named D. $x$ ambroseae Fraser-Jenkins \& Jermy, and although not recorded from the Iberian Peninsula, it could occur where D. dilatata and D. expansa grow together. Meiosis in both the wild and synthesised hybrids shows approximately 41 bivalents and 41 univalents, (range 33 to 41 bivalents with 57 to 41 univalents). Since D. dilatata is an allotetraploid, the bivalents in the hybrid must represent pairing between one set of chromosomes from D. dilatata and those of D. expansa (see Fig. 2).

Triploid hybrids have also been synthesised between D. dilatata and D. maderensis. These are similar to $D$. $x$ ambroseae in showing 34 to 37 bivalents and correspondingly 55 to 49 univalents (Walker, 1955). Similarly synthetic triploid hybrids of D. azorica $x$ dilatata show 40 to 41 bivalents with 43 to 41 univalents (Gibby \& Walker, 1977). This hybrid could occur in the wild since the two parents grow together on Pico in the Azores. The results obtained from these triploid hybrids, $D$. dilatata $x$ maderensis and D.azorica $x$ dilatata, suggest that the two diploids, D. maderensis and D. azorica also represent a parent of D. dilatata. To clarify whether they represent the same parent as D. expansa, or the second parent of D. dilatata, attempts were made to synthesise diploid hybrids. Only one attempted hybridisation was successful, that between D. azorica and D. expansa. The hybrid is intermediate between the parents in morphology, and during the first division of meiosis shows practically complete absence of chromosome pairing, with 2 to 6 bivalents (average 3.3) and 78 to 70 univalents recorded (Gibby, 1977). Clearly the two diploid species involved in this hybrid have not got similar genomes, and it seems likely that D. dilatata arose by hybridisation between 
D. azorica and D. expansa, with subsequent chromosome duplication (see Fig. 2). The similarity in morphology between diploid hybrid, D. azorica $x$ expansa, an D. dilatata supports this theory. Unfortunately it has not yet proven possible to synthesise D. dilatata from the diploid hybrid by inducing chromosome doubling. The bivalents in the triploid hybrid $D$. azorica $x$ dilatata must involve one genome of D. dilatata (the C genome; see Fig. 2) and a genome of D. azorica. The relationship of D. maderensis with D. azorica and D. expansa has not been identified clearly. However, D. maderensis shows many similarities with D. azorica in the morphology, chemistry and spore size, and it is probable that it represents the same genome as D. azorica; the few morphological differences between the two may well reflect their long isolation on separate island groups.

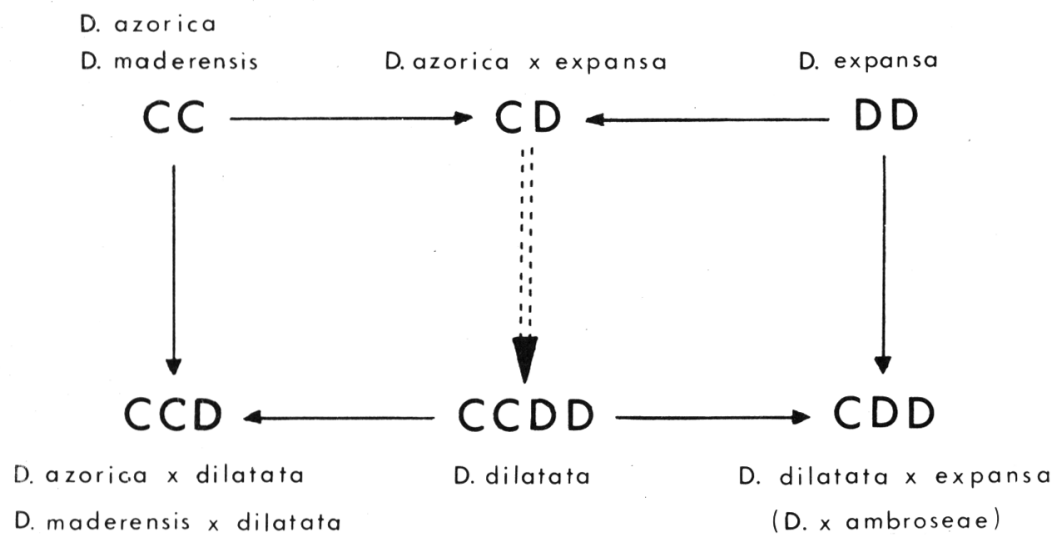

Figure 2.- Explanatory diagram showing the genomic relationships of D. azorica, D. maderensis, D. expansa and D. dilatata.

A similar hybridisation programme was initiated between D. carthusiana and the diploid species of the complex. No successful crosses have been synthesised between D. carthusiana and D. expansa; however, a wild triploid hybrid of this putative parentage was reported from Finland (Sorsa and Widén, 1968). This hybrid has been named D. $x$ sarvelae Fraser-Jenkins and Jermy. Cytological analysis of the hybrid reveals it to be triploid, and most of the chromosomes appear as univalents during first metaphase of meiosis (Gibby \& Walker, 1977); 0 to 8 bivalents (average 2.6) and 123 to 107 univalents were recorded (see Plate 4 ). This result suggests that D. expansa is unrelated to D. carthusiana, and that D. carthusiana is an allotetraploid species (see Fig. 3). Further evidence for the allotetraploid nature of D. carthusiana is obtained from another wild triploid hybrid involving D. carthusiana and the diploid D. marginalis (L.) A. Gray. D. marginalis is easily distinguished from other Dryopteris species by the marginal position of the sori, and these 


\section{GIBBY}

are in an intermediate position in the hybrid D. cartusiana $\mathbf{x}$ marginalis. At meiosis 0 to 8 bivalents were recorded, with 123-107 univalents (Wagner, 1971).

Synthesised hybrids of D. carthusiana with D. maderensis and with D. azorica show approximately equal numbers of bivalents and univalents (Walker, 1955; Gibby \& Walker, 1977); this suggests that both represent a parent of D. carthusiana (see Fig. 3). The second parental diploid of D. carthusiana (the 'BB' parent; see Fig. 3) is at present unknown.

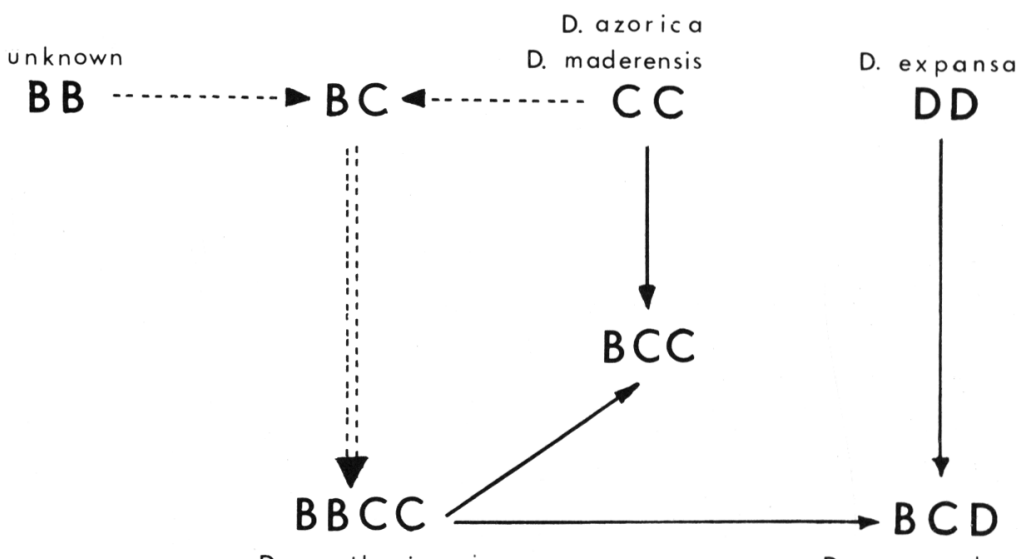

Figure 3.- Explanatory diagram showing the genomic relationships of D. azorica, D. maderensis, D. expansa and D. carthusiana.

Confirmation that D. dilatata and D. carthusiana share a common genome, the genome ' $C C$ ' represented by $\mathrm{D}$. azorica and $\mathrm{D}$. maderensis, is obtained from analysis of meiosis in the hybrid between these two tetraploids. This hybrid, D. $x$ deweveri (Jansen) Jansen \& Wachter is fairly common in the wild, and has been recorded from northwest Spain (Franser-Jenkins \& Jermy, 1977. Since it is a cross of D. dilatata (CCDD) with D. carthusiana ( $B B C C)$, the genomic formula of the hybrid can be represented as BCCD. Analysis of meiosis in the hybrid shows about 41 bivalents and 82 univalents, the bivalents represented pairing between the two ' $\mathrm{C}$ ' genomes.

The identity of tetraploid D. guanchica as a species separate from D. dilatata was suspected when hybrids were synthesised between D. guanchica and D. aemula. Many attempts have made to hybridise D. aemula with D. dilatata but without success, yet the first attempt to produce triploid $D$. aemula $x$ guanchica succeeded. The hybrid shows 37-41 bivalents with 49-41 univalents (Plate 5). Later, wild hybrids from Gomera of this putative combination were found to show a similar result. The bivalents present in the triploid hybrid could represent pairing between the genome of $D$. aemula and one genome from D. guanchica, if D. guanchica were allotetraploid, or could represent pairing between the two genomes within D. guan- 
chica, if this species were autopolyploid and D. aemula were an unrelated diploid. The allopolyploid nature of D. guanchica has been established by hybridising it with an unrelated diploid, D. marginalis. The triploid $D$. guanchica $x$ marginalis was easily identified by the intermediate position of the sori; at meiosis it shows practically no bivalent formation, which suggests that D. guanchica is an allotetraploid. D. aemula must represent one of its parents. On morphological comparisons it was believed that D. maderensis may represent the second diploid parent of D. guanchica. Two triploid hybrids of the combination D guanchica $\mathbf{x}$ maderensis were synthesised. Analysis of meiotic pairing showed 35 to 41 bivalents (average 40.0) with 53 to 41 univalents. D. maderensis appears to represent a parental diploid of D. guanchica (see Fig. 4). The synthesis of two diploid hybrids of D. aemula $x$ maderensis confirmed that $D$. aemula and D. maderensis have different genomes, since no chromosome pairing was seen in any of the 10 cells analysed. Comparisor of the morphology of the diploid hybrid with D. guanchica reveals some similarities; however, synthesis of D. guanchica from the hybrid by chromosome duplication has not yet been achieved. Figure 4 indicates the probable origin of D. guanchica. Little is known of

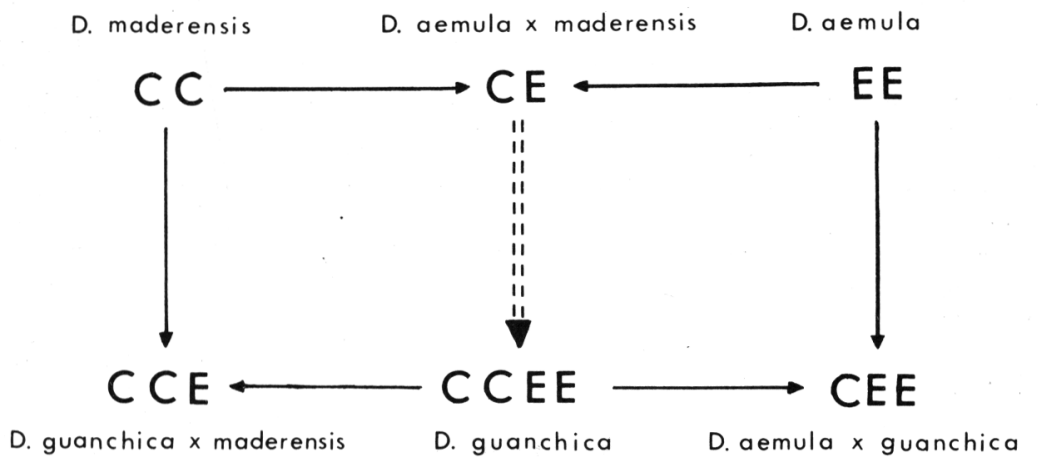

Figure 4.- Explanatory diagram showing the genomic relationships of D maderensis, D. aemula and D. guanchica.

the cytogenetical relationships of D. crispifolia. An attempt has been made to synthesise hybrids between this species and other members of the D. dilatata complex. Unfortunately the hybrids which have been synthesised have not yet become fertile and so it has not been possible to analyse meiosis in these hybrids. The problem is not one of age - some of the hybrids are now six years old - but it may result from the growing conditions in London, which may not be ideal for D. crispifolia and its hybrids. On morphological grounds, Rasbach and Reichstein have suggested that D crispifolia has evolved from D. aemula and D. azorica, by hybridisation and chromosome doubling. The three species do grow together in the Azores, and it is likely that the tetraploid arose here. If this is the parentage of 


\section{GIBBY}

D. crispifolia, it would have the genomic formula CCEE; this is the same as D. guanchica. The difference in morphology between D. crispifolia and D. guanchica may reflect the different origin of the CC genorne in these tetraploids, perhaps being derived from D. azorica in D. crispifolia, and from D. maderensis in D. guanchica.

Perhaps one of the strange results from this investigation has been the discovery that of the two tetraploids whose origins have been clarified, D. dilatata and D. guanchica, neither grows today in association with both diploid parents. D. dilatata occurs with D. expansa in Europe, and with D. azorica in Pico, but the two diploids are not sympatric. Similarly in the case of D. guanchica, D. aemula and D. maderensis do grow together in Madeira, but the tetraploid is not known here, and is found only in the Canary Islands and the Iberian Peninsüla.

\begin{tabular}{|l|c|cccc|}
\hline Species & Ploidy & Azores & Madeira & $\begin{array}{c}\text { Canary } \\
\text { Islands }\end{array}$ & $\begin{array}{c}\text { Iberian } \\
\text { Peninsula }\end{array}$ \\
\hline D. aemula & $2 \mathbf{x}$ & $\mathrm{X}$ & $\mathrm{X}$ & $\mathrm{X}$ & $\mathrm{X}$ \\
\hline D. expansa & $2 \mathbf{x}$ & & & $\mathrm{X}$ \\
\hline D. azorica & $2 \mathrm{x}$ & $\mathrm{X}$ & $\mathrm{X}$ & $\mathrm{X}$ \\
\hline D. maderensis & $2 \mathrm{x}$ & & & $\mathrm{X}$ \\
\hline D. dilatata & $\mathbf{4 x}$ & $\mathrm{X}$ & $\mathrm{X}$ & $\mathrm{X}$ \\
\hline D. carthusiana & $\mathbf{4 x}$ & & & \\
\hline D. guanchica & $\mathbf{4 x}$ & & $\mathrm{X}$ & \\
\hline D. crispifolia & $\mathbf{4 x}$ & & & \\
\hline
\end{tabular}

\section{REFERENCES}

FRASER-JENKINS, C.R. and JERMY, A.C. - 1977 - Nomenclatural notes on Dryopteris: 2. Fern Gaz., 11: 338-340.

GIBBY, M. - 1977 - A cytogenetic and taxonomic study of the Dryopteris carthusiana complex. Unpublished $\mathrm{Ph}$. D. thesis, University of Liverpool.

GIBBY, M., JERMY,A.C., RASBACH, H., RASBACH, K., REICHSTEIN, T. and VIDA, G. - 1977 - The genus Dryopteris in the Canary Islands and Azores and the description of two new tetraploid species. Bot. J. Linn. Soc., 74: 251-277.

GIBBY, M. and WALKER, S. - 1977 - Further cytogenetic studies and reappraisal of the diploid ancestry in the Dryopteris carthusiana complex. Fern Gaz., 11: 313-324.

LOVIS, J.D. - 1968 - Fern hybridists and fern hybridisong. II. Fern hybridising at the University of Leeds. Brit.Fern Gaz., 10: 13-20.

MANTON, I. - 1950 - Probiems of cytology and evolution in the Pteridophy- 
ta. pp 316. Cambridge University Press.

MANTON, I. and WALKER, S. - 1954 - Induced apogamy in Dryopteris dilatata (Hoffm.) A. Gray and D. filix-mas (L.) Schott emend. and its significance for the interpretation of the two species. Ann. Bot. N. S. 18: 377-383.

SORSA, V. and WIDEN, C.J. - 1968 - The Dryopteris spinulosa complex in Finland. A cytological and chromatographic study of some hybrids. Hereditas, 60: 273-293.

WAGNER, W.H.Jr. - 1971 - Evolution of Dryopteris in relation to the Appalachians. pp 147-192 in P.C. Holt ed. The distributional history of the biota of the Appalachians. Part II. Flora (Res. Divi. Monogr. 2). Blacksburg, Virginia: Virginia Polytech. Inst. and State University.

WALKER, S. - 1955 - Cytogenetic studies in the Dryopteris spinulosa complex. Watsonia, 3: 193-209.

Comunicación presentada a la Reunión

Internacional de Pteridología(Algeciras,1980)

Dirección del autor: British, Museum, Cromwell Road, London, England. 

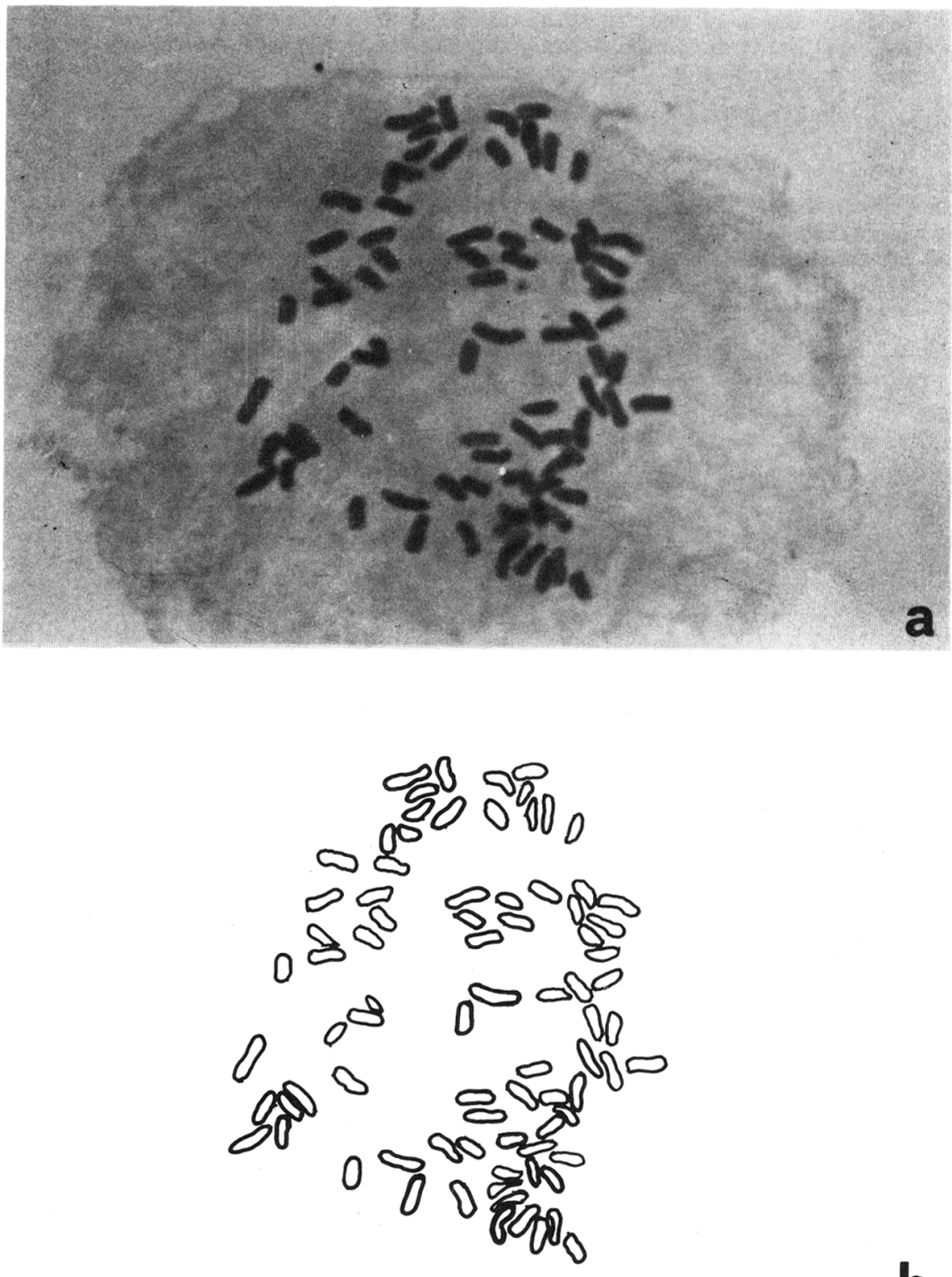

b

Plate 1.- Dryopteris azorica from Faial, Azores, no. University of Leicester 3649.

a. Root tip preparation, showing mitotic metaphase (x 1500)

b. Explanatory diagram, showing 82 chromosomes 

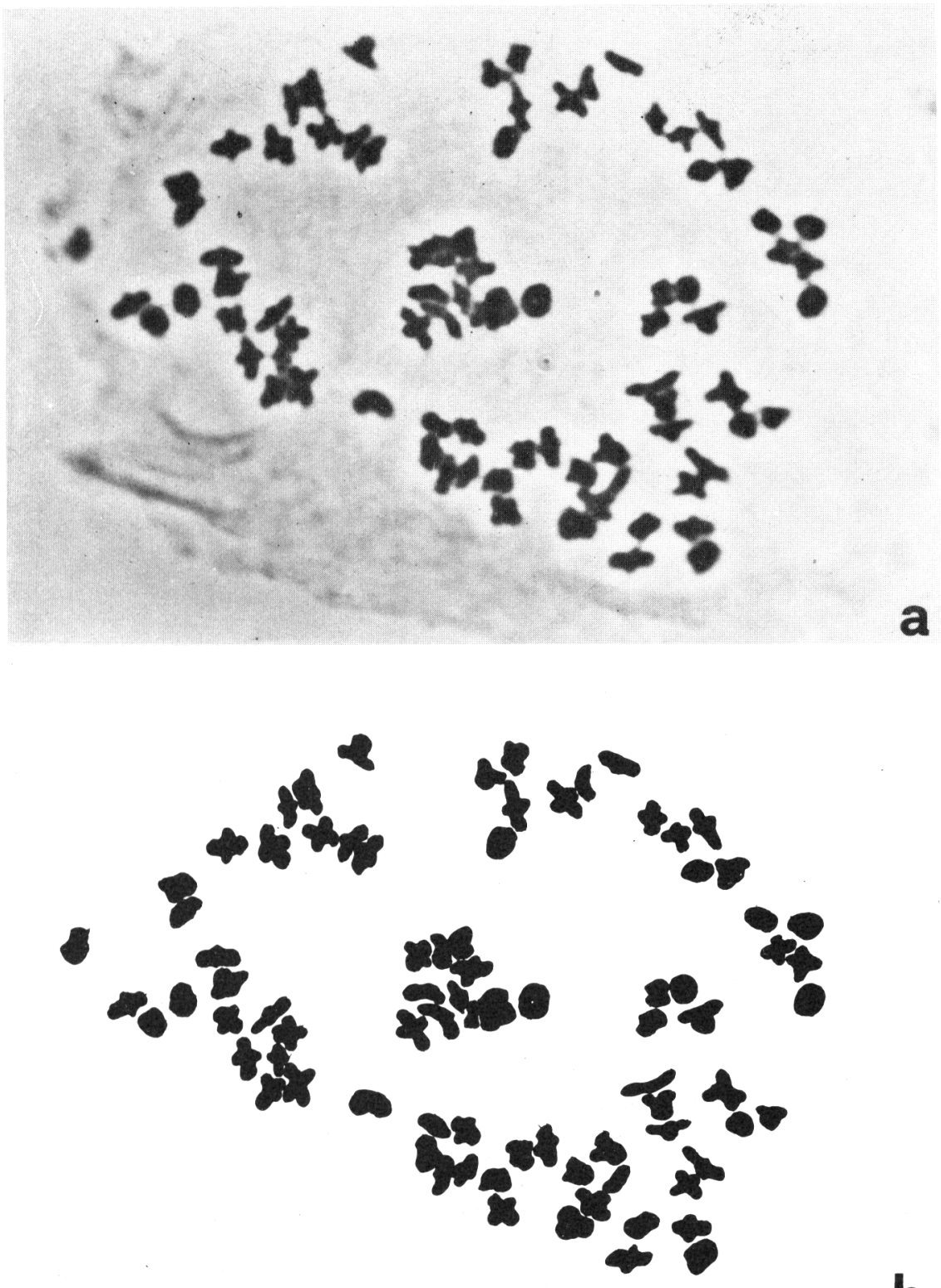

b

Plate 2.- Dryopteris crispifolia from Pico, Azores, Coll.

T. Reichstein no. 3530.

a. Spore mother cell preparation, showing first metaphase of meiosis ( $x$ 1500)

b. Explanatory diagram, showing 82 bivalents (in black) 
M. GIBBY
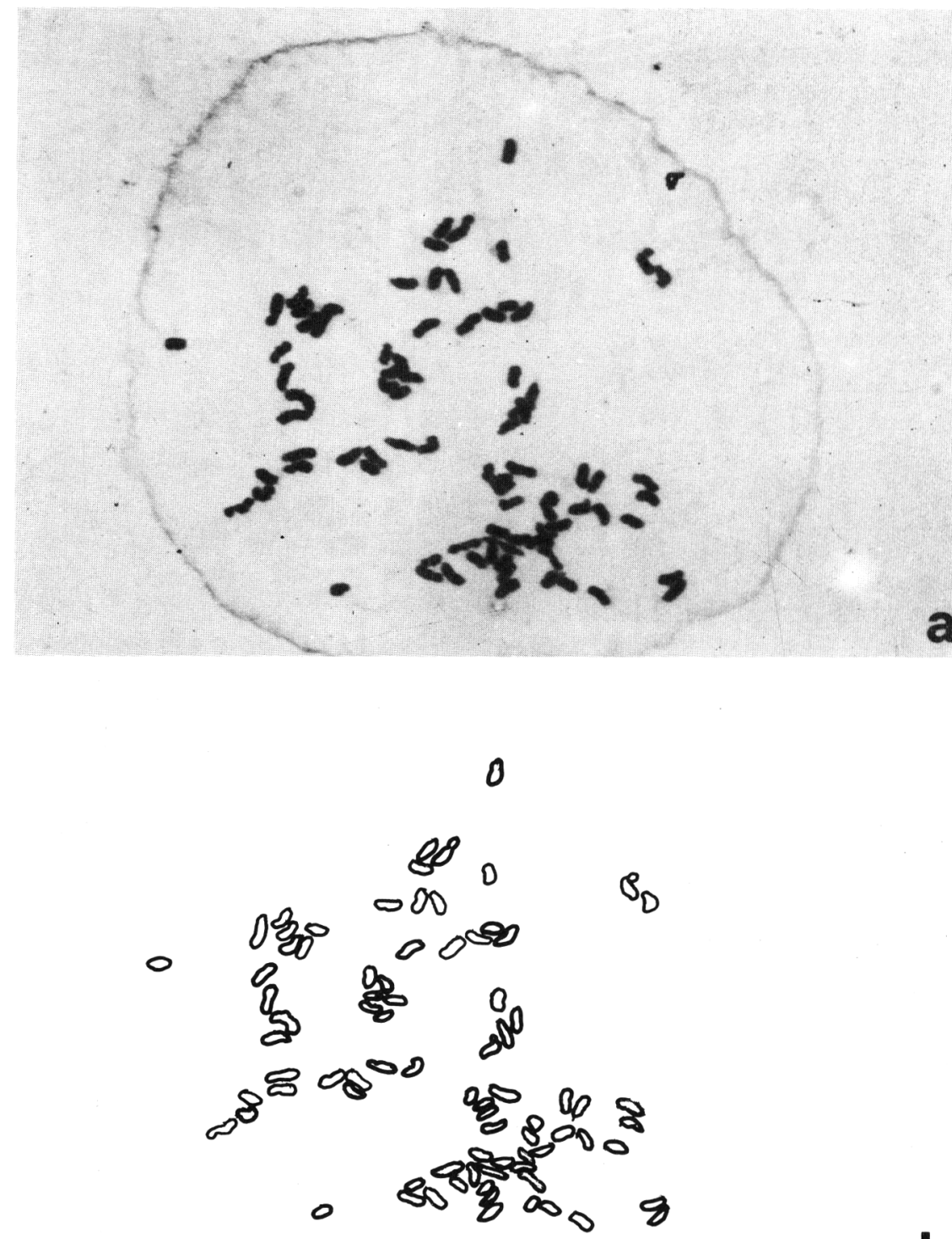

b

Plate 3.- Dryopteris dilatata, dihaploid, from University of Leeds Botanic Garden.

a. Spore mother cell preparation, Showing first metaphase of meiosis ( $x$ 1500)

b. Explanatory diagram, showing 82 univalents (outlined) 

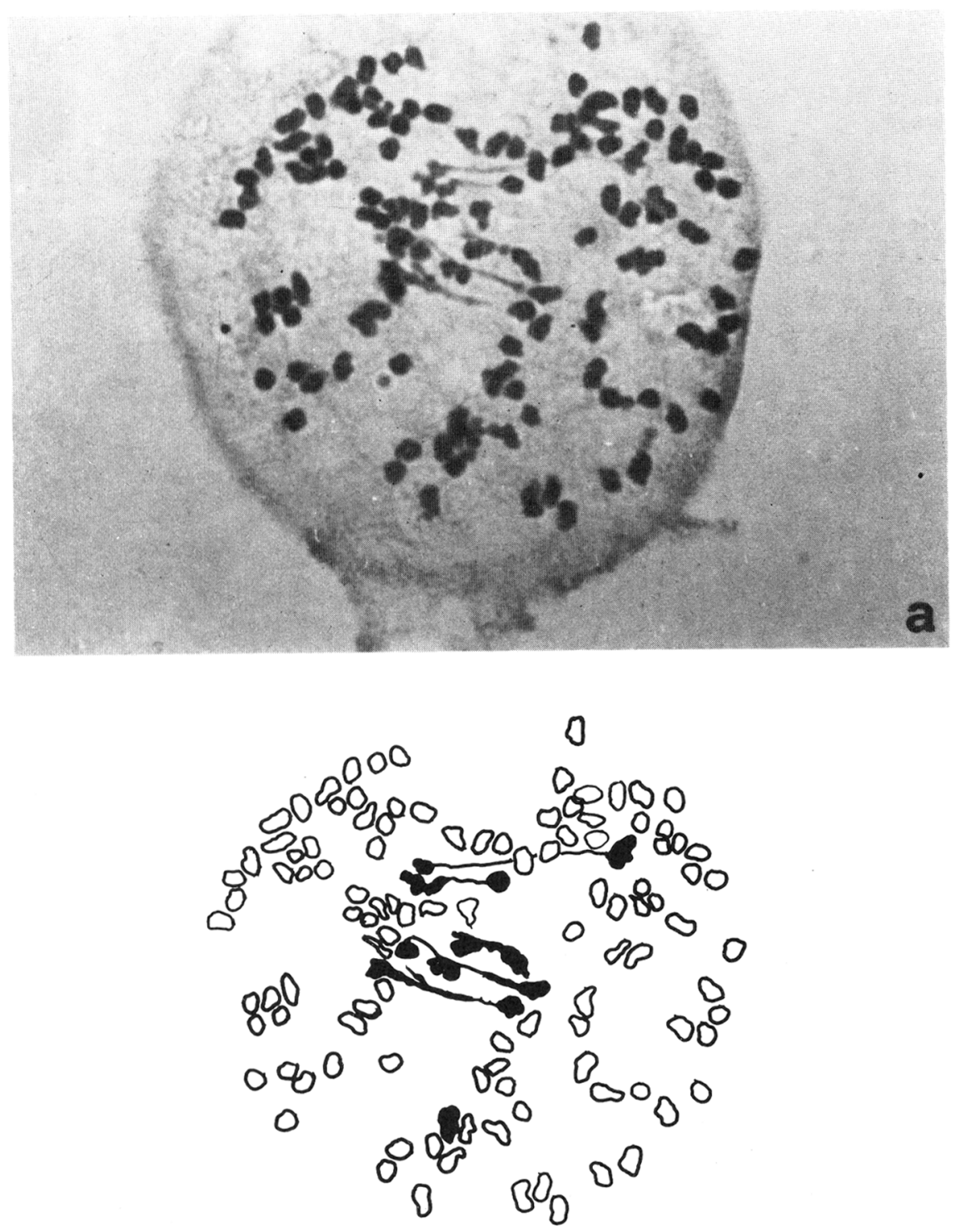

b

Plate 4.- Dryopteris $x$ sarvelae from Espoo, Finland, coll.

J. Sarvela no. 19.

a. Spore mother cell preparation, showing first metaphase of meiosis (x 1500)

b. Explanatory diagram, showing six bivalents (in black) arrd 111 univalents (outlined) 
M. GIBBY
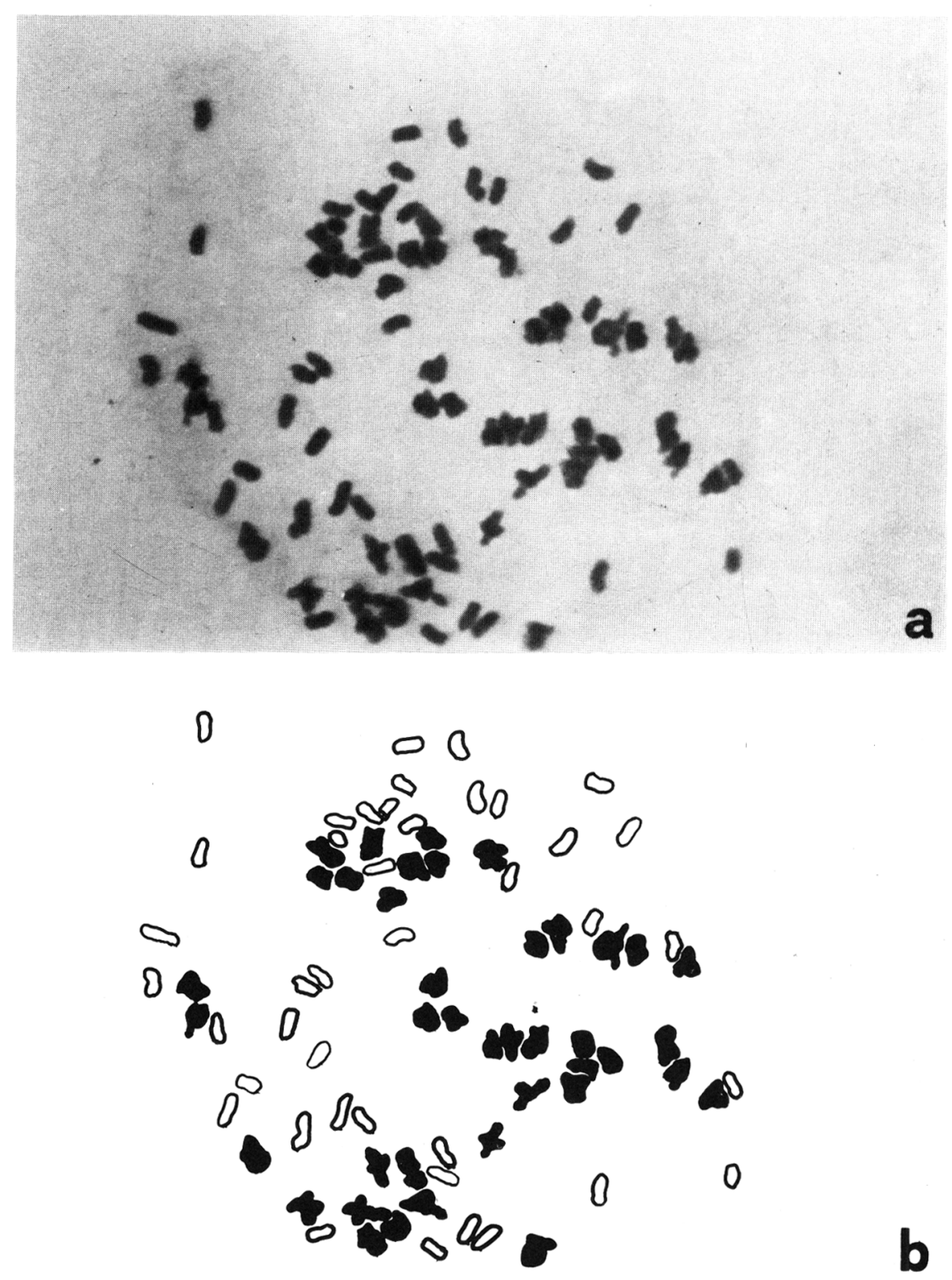

b

Plate 5.- Synthesised hybrid of Dryopteris aemula $\mathrm{x}$ guanchica, no. H 358 ivb.

a. Spore mother cell preparation, showing first metaphase meiosis ( $x$ 1500)

b. Explanatory diagram, showing 41 bivalents (in black) and 41 univalents (outlined) 